\title{
Henri Prost in Istanbul: Urban transformation process of Taksim-Maçka Valley (Le parc n²)
}

\author{
Pelin Bolca, Rosa Tamborrino, Fulvio Rinaudo \\ Department of Architecture. Politecnico di Torino. Torino, Italy \\ E-mail: pelin.bolca@polito.it, rosa.tamborrino@polito.it, \\ fulvio.rinaudo@polito.it
}

\begin{abstract}
With the foundation of the Republic of Turkey in 1923, modernization studies have been started throughout the country. Following this, French architect and urban planner Henri Prost was invited to conduct the planning of Istanbul. He worked with conservative and modernist attitude. He gave importance on open spaces and public parks. His largest public park proposal was Park No2 which was the area extending from today's Taksim Square to Maçka Valley and this park was fully constructed in the 1940s. However, it has been transformed by the planning decisions taken over time depending on the political, cultural and ideological changes. The focus of this study is to understand and define the process of transformation, and investigate the changing of significances and cultural values of the Taksim-Maçka Valley from foundation of the Republic of Turkey to the present day. Accordingly, the first part of the paper presents the formation process of the area through the plans which was prepared by Henri Prost. In the second part, the transformation process of the area on the Prost's legacy is analyzed.
\end{abstract}

Keywords: Digital heritage, Prost, Istanbul, public park, cultural landscape

\section{Introduction}

Cultural Heritage is a notion conceived and continuously changed in the last two centuries readapting theoretical assumptions practices and practices to new achievements and cultural developments. Nevertheless this notion also developed differently in diffentent cultural and political frameworks, in Europe and in other countries.

The fate of Istanbul, the old capital city of Ottoman Empire, changed with the end of the First World War. Ottoman Empire collapsed and in 1923, Republic of Turkey was founded under the leadership of Mustafa Kemal Atatürk. The Republic of Turkey represented a significant turning point in Turkish history. This new period was the starting point of a modernization process that includes with change of the country's political and social structure such as figures and symbols of the
Ottoman Empire and their replacement with secular values for the new nation-state (Çelik, 1993). As a result of this, the Republican authorities had decided to transfer the political capital to Ankara, thus, Istanbul lost its status. In those years, shaping the cities according to modernization approach was also important to creation of new state after long war period. Therefore, Republican authorities perceived urban planning as one of the principal works to form new state as well as to satisfy the needs of industrial age (Bozdoğan, 2002).

Priority of limited funds was given to Ankara, new capital city of the state. After the creation of modern Ankara, according to the Jansen Plan, the Republican Government turned its attention to the planning of Istanbul. The fact that Istanbul was the old empire capital with the traditional Ottoman life, made it a perfect stage to bring the modern city life and to make the secular character of the new regime visible. 
In 1933, to obtain a plan for Istanbul, an urban competition was organized by the municipality. The international specialists -Henri Prost, Donat Alfred Agache, Hermann Ehlgötz- were invited to submit three proposals for the future of Istanbul (Bilsel, 2010). The three architects were then the leading figures who contributed to the creation of the urbanism as a discipline. This condition influenced the choice of their invitation. The German urbanist Herman Elgötz was known for his successful plans for various cities, and in particular, Essen, the German industrial city. Agache and Prost were effective and essential members of French Musée Social, which was an important and leading research center into city planning, social housing and labor organization in Paris (Cohen, 2010). In particular, Prost was playing an important role in Musée Social. He was assistant of Eugène Hénard who was the head of the committee for identifying urban and rural hygiene problems and proposing solutions (Cohen, 2010). Prost's new cities studies within the intellectual atmosphere of the Musée Social affected his works. Besides, he was also known as author of comprehensive planning works for several cities, such as Fez, Marrakesh, Meknes, Rabat and Casablanca (Hautecoeur,1960). Nevertheless, he was also engaged in the direction of the regional planning studies of the metropolitan area of Paris, caused to decline the invitation. Prost suggested his colleague Jacques Henri Lambert to his task. Agache, Lambert and Ehlgötz prepared their proposals. Although Ehlgötz's plan was finally chosen, his plan never was put into implementation. In 1935, in fact, Henri Prost was formally invited by the municipality of Istanbul to conduct the planning of the city. In addition to being one of the leading figures of the period, his planning of Paris, the one of the most important modern urbanism phase, had affected to make the decision of entrusting to him the future developments of Istanbul. For this purpose first he established a City Planning Office in the Istanbul municipality - that was under construction at that time - where he undertaken his task with the role of head of Planning Office of Istanbul between 1936 and 1951. In other words, Prost became not just the urban planner of Istanbul but also the founder and the chief of the new devoted department for planning (Pinon, 2010). In this context he was teaching the employees of the Planning Office by building new expertise

In these fifteen years, he worked for several urban studies such as masterplans and detailed projects. HenriProstbased his studies of Istanbul on three principal issues: transportation (la circulation), hygiene (l'hygiene) and aesthetics (l'esthetique) (Bilsel, 2010). He also took into consideration the diversity of Istanbul as a city above by different, and has planned it with a poly-centered approach (old city on Historical Peninsula/new city on Pera). Regarding his hygiene (l'hygiene) issue on Istanbul, he proposed several public open spaces as defined with his words, espaces libres. Prost's open spaces included a system of parks, promenades, squares, terraces, boulevards, sports areas (Fonds Henri Prost,Paris). Within these open space proposals, the largest public park proposal was for the urban region of 'core of Pera', which extends from the today's Taksim Square to Maçka Valley where modern city settlement has expanded (Figure 1). The fact that Taksim Square was an effective symbol of the Republic hosting the first Republican Monument of Istanbul (located there in 1928), was an important influence of his decision.

The park named Park No2 (parc n'2) conceived by Prost was not only a public park. He also included public building blocks with cultural, sportive and art functions. Such decisions taken by Prost show us the area was not considered the park just as a recreation area, but as a green pattern with public services inside the city center.

As soon as in 1950, the political policy was changed and the multy-party regime was started for Turkey. Prost the following year (1951) was discharged from his position by this new regime that adopted the policies of Turkishness (Akpınar, 2010). Interrupted the plan and broken the perspectives given by Prost, over the time the area has been transformed by the planning decisions taken over time depending on the political, cultural and ideological changes.

This paper aims to study contribute to shape the historical formation process of the area of Park No 2 as a cultural heritage of modern 


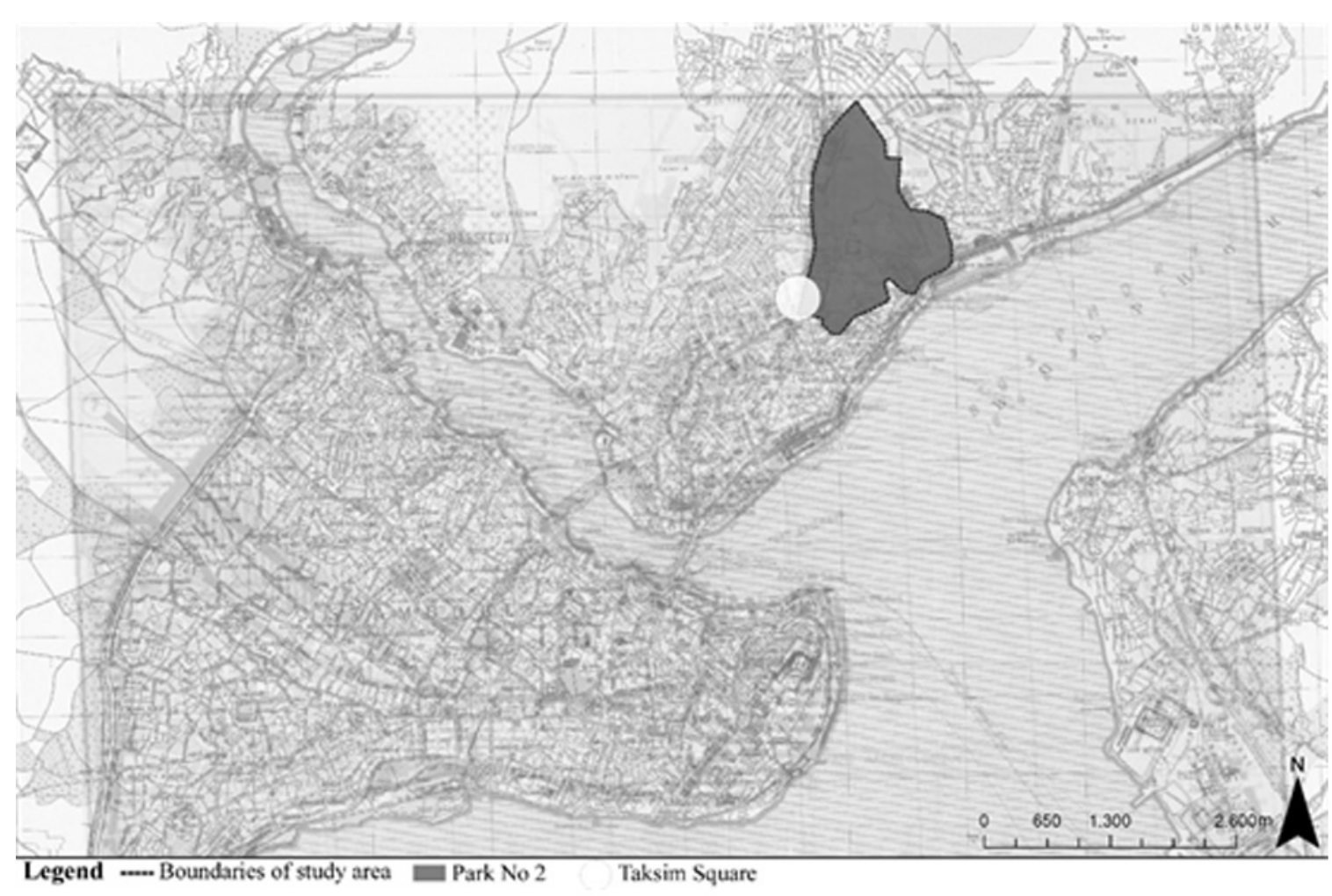

Figure 1. Park No 2; Basemaps 1:17500 Plan d'Ensamble De La Villa De Constantinople-1922 (Harvard Map Collection) and the informations from the program of the masterplan (Le programme du plan directeur) (Prost,1937) are georeferenced by the author (Software: ArcGIS)

Istanbul. The notion of a 'Cultural Heritage of the Republic of Turkey' of Taksim Square and Gezi Park is under discussion nowadays. The main focus of the study is to identify the dynamic of transformations of this urban area by checking its deteriorations of the Prost's legacy.

\section{Methodology}

Considering the significant urban heritage and the range of histoircal changes of the Taksim-Maçka Valley, they present a perfect case study focusing on transformation and analyzing Prost's legacy. In order to be able to exemplify the case of Taksim-Maçka Valley within the framework drawn above 'digital urban history method'(telling the history in the age of the ICT revolution) (Tamborrino, 2014) have been used. 'Digital humanities' represent an innovative alternative to use of Information and Communication Technologies
(ICT) techniques as use of digital tools. Having use of this technique, digital technologies offer a new approach as a new interpretation key to make it possible to understand the architectural / historical outcomes and Cultural Heritage(Warwick\&Terras\&Nyhan, 2012). In this study, the method is used for obtaining, processing data/information and for evolution of the outcomes. Visualization and spatialization of data have been concieved as a part of the methodology as a final demonstration but also as a research approach (Bodenhamer\&Corrigan\& Harris, 2010).

Obtaining of data had done through the light of various direct and indirect sources: literature view, site survey, visiting governmental agencies and archives. These data are processed through mainly using ArcGIS software and 3D modeling techniques. The reason for the selection of the software is its easing the make a comparative study rectifying different maps and data information prepared in different years with the same accuracy. 
Henri Prost in Istanbul: formation process of the Parc No 2

In 1940, Prost prepared 1:2000 scaled masterplan for Park No 2 (plan parc no'2) (Fonds Henri Prost,Paris). Since the area had been defined as a military area by Sultan Mahmut II, a 'barrack construction' movement began on the area until the last period of Ottoman Empire (Tekeli,1996). However, barracks were abandoned at the First World War era and the area was started to use as a public park by the habitants. Therefore, when Prost came to charge, numerous significant Ottoman structures were present on the area. In his planning decisions of Istanbul, Prost put special importance on preservation of heritage. As a reflection of this attitude, he protected a great number of Ottoman structures at the area of Park No 2 by giving them new cultural and educational functions. Topçu Barracks (Halil Pasha Artillery Barracks, the military building that was built in 1806) located at Taksim Square was the only building that Prost proposed to be demolished. During First World War, it had been abandoned and since 1921 the courtyard of the Topçu Barracks had been using as a stadium by the community (Çiftçi,2004). Also, the fact that the Republican authorities want to use the main square as a wide celebration area affected to Prost's Taksim Square plans.

Surroundings of the area were defined as a new settlement area to mark the character of the Republic's new modern life. The park was located at the core of the new settlement zone. The functions of buildings included in the park plan were also important at the large urban scale. Therefore, Prost added the Municipal Club, Dolmabahçe Stadium, Sports and Exhibition Hall and the Amphitheater to his Park No 2 Plan (Leveau,1960). Thus, he considered the area as a whole as a public park by modern cultural notions.

In addition, Prost used the area's topography features on his planning decisions. Thus, the slopes of the Maçka Valley was planned as a fully recreational area by integrating functions of buildings and open spaces. Thus, inside the park, cafes (significantly called by Prost as belvédère) were designed by the launch of the specific competitions for the Bosphorus view.
Besides, the settlement of the public buildings was also chosen compatible with the heights of the buildings which date to Ottoman Period and topography.

The first implementation was to demolish Topçu Barracks and construct the so called Gezi Park with the compliance of Taksim Square accomplished in 1943 (Güzelleşen Istanbul,1943). However, although Prost was discharged from his position, until 1950 the implementation of the Park No 2 was almost finished and all proposal building blocks have been built (Figure 2). Immediately, the Park No 2 has also adopted and started to use in everyday life by the community. In addition, the following years, Prost's plan for Istanbul continued to affect the city's urban formation/ transformation process.

\section{Transformation process of the area on Henri Prost's legacy}

1950s marked the new regimes abandonment the secular attitudes, stating economic policies and nationalist self-sufficiency of the previous regime. With the new regime, the model of the cultural politics of the nation was shifted from 'European' to 'American' (Bozdoğan\&Akcan,2013). As a reflection of these notions, Istanbul's first Hilton Hotel was constructed (Skidmore-Owings-Merrill,SOM was invited to design its project in 1951) and Prost's Park No'2 was selected as its location. Thus, the first deterioration of the area has been realized. Then, in 1959, the Municipal Club located at Gezi Park that was realized as a Prost's proposal was demolished to construct Sheraton Hotel (today's Intercontinental Hotel) (Figure 3) These implementations marked the beginning of radical changing of the conception of the urban area. Shifting its functions from collective monumental significances to touristic and private target.

The Taksim-Maçka Valley's transformation process has gained a different direction with masterplans, development plans and laws that where approved in 1980s. An important legal change that affected the planning approach was Law No. 2634 enacted on March 12, 1982, was entitled as 'Tourism Promotion Law'(Turizm 
Teşvik Kanunu) (Official Gazette, 31.07.1984). Its aim which was allowed the central government to declare certain strategic sites as 'Tourism Centers' caused worries about the implementation of the law in the academic and professional field (Enli1,2011). The first determined tourism centers were located in Taksim-Maçka Valley. This law has led to the construction of very contradictive hotels in the area and the projects of the hotel buildings foreseen to be built in the framework of the law were published with named as Taksim/ Maçka Tourism Center. The valley has been the most discussed and criticized area among the tourism centers determined throughout Istanbul (Ekinci, 1993).

Meanwhile, Habitat II, the Second United Nations Conference on Human Settlements was held in Istanbul from June 3-14, 1996. In order to be able to held various events for the conference, Taksim-Maçka Valley was declared as a 'Congress Valley'. This decision was another significant turning point of the areas transformation. From these events, the area hosted many international congresses and several events to the NATO Summit in 2004.

As a consequence, the collection of buildings, functions, private stakeholders was added to the park by compromising its perception as a current project. Despite the general project of a park as a whole, including open spaces, buildings, public functions, a preservation law distinguish between them by separating the monuments. In accordance with Legislation No.10521 of Turkey the Council of Preservation of Cultural and Natural Heritage (Türkiye Kültür ve Tabiat Varlıklarını Koruma Kurulu) which was dated on 06.01.1999, four elements (corresponding in percentage to the $7.5 \%$ of Park No 2) are mentioned that establish Taksim Square, form a whole with each other and indicate that all must be preserved. These are Maksem, AKM (Atatürk Cultural Center), Republican Monument and Gezi Park (UCTEA Istanbul Branch Online Archive). However, until 1990s although the declines had been

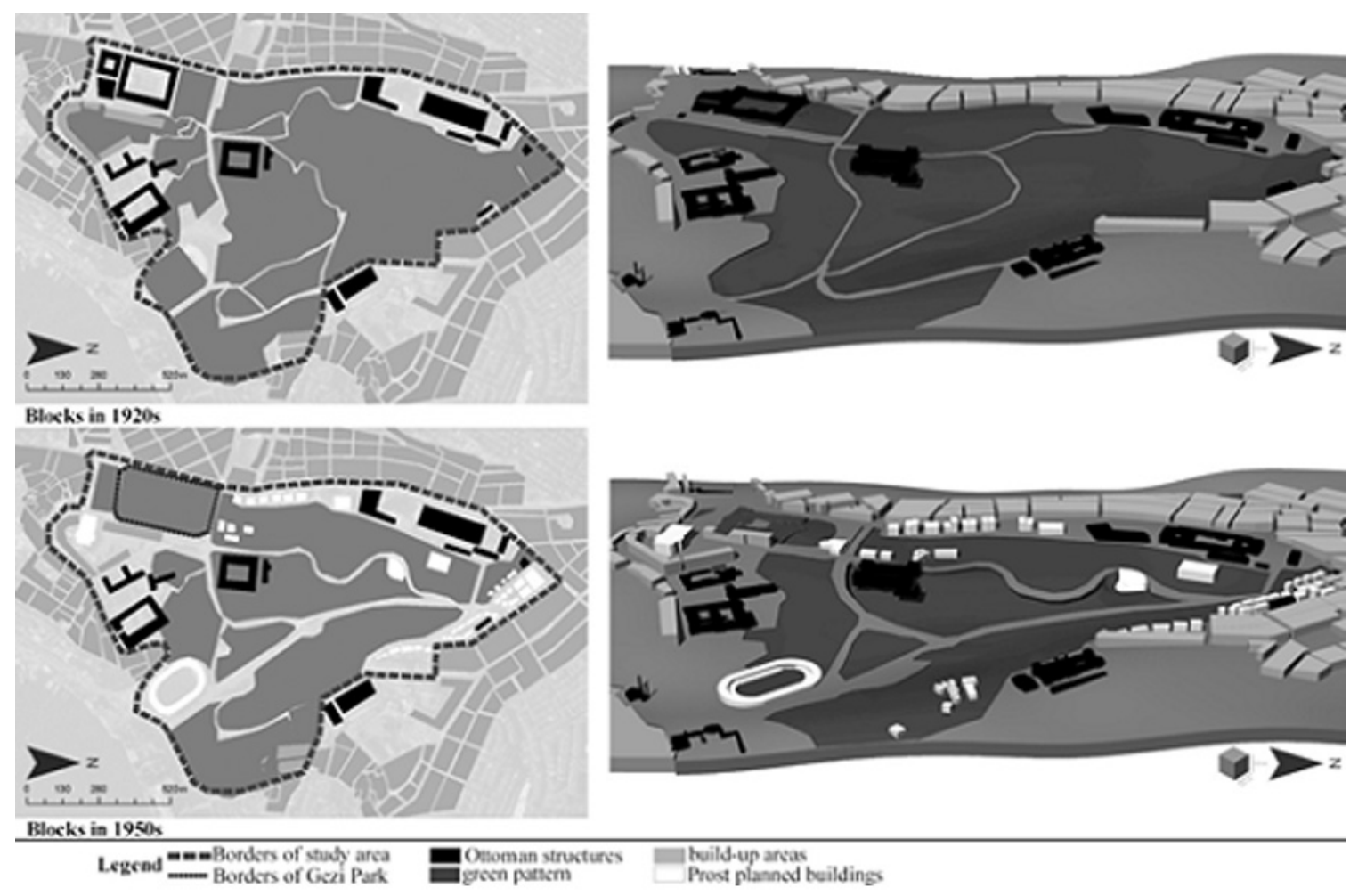

Figure 2. Blocks in 1920s and 1950s; Basemap World Imagery and the information from 1:17500 Plan d'Ensamble De La Villa De Constantinople-1922 (Harvard Map Collection) and the information from 1:2000 Plan de Reference-1940 (Leveau,1960) are spatialized by the author (Software: ArcGIS\& Rhinoceros) 
realized, the green pattern of the area had been still present (Figure 4).

Taksim-Maçka Valley - particularly Gezi Park- has been discussed intensively by the academic and professional field at the last decades. 2000's marked an acceleration of urban transformation studies above Istanbul in a questionable way on urban agenda. According to Turkish architects and urbanists (Dinçer, 2010), legal changes and urban renewal/ transformation projects in 2000 s that facilitates urban interventions is not a coincidence but an effort to set a base enabling economic policies. In 2011 the government's announcement of the 'Taksim reorganization urban project' included the pedestrianization of the square by the expansion of streets to be re-organized underground and the reconstruction of Topçu Barracks (the one had been demolished at 1940 for the formation of Gezi Park). The reconstruction of the Barracks would mean the latest change of Park No 2, fully destruction of the Gezi Park the final remaining cultural legacy of the Prost's project for Istanbul. The project caused objections and it was brought to court. These contrapositions were a turning point with protests were/are called Gezi Park Protests. Finally, the Istanbul 6thAdministrative Court has adopt a motion for stay of execution of 'Reconstraction of Topçu Barracks Project' and 'Taksim Pedestrianization Project'. In the meantime, the pedestrianization project had been realized as well as the construction of hotels, conference halls and a shopping mall continued to transform of the Park No 2 (Figure 5). But demolition of Gezi Park was not realized.

\section{Conclusion}

Henri Prost's studies on the planning of Istanbul were put into implementation through a series of urban operations in the aim of collective. The main idea was to modernize the social life through modern public spaces that did not exist in Ottoman traditional life. Achieving this aim has led to shaping of Park No 2 by integrating green spaces with public buildings. But the spatial GIS analysis further indicate that there has been a considerable change of urban land use since then. In the 1950s, the ratio of public buildings to the total built-up area was $73 \%$. It has continuously decreased: in the 1980 s it was $60 \%$, in 1990 s it was $49 \%$ and finally the ratio of the current situation is corresponding to $48 \%$.

On the other hand, according to the informations gathered from the aerial photos through GIS, the overlay of the green spaces has a decreasing ratio since the 1950s. When Prost finished his service in Turkey in 1951, the ratio of green spaces to total area was $76 \%$. Then, in the 1980 s it was $71 \%$, in 1990 s it was $62 \%$. Today, this green spaces ratio to the overall urban space is around $28 \%$ (the Gezi Park constitutes $17 \%$ of this ratio).

By this computation results, it can be observed that the identity of Taksim-Maçka Valley has been heavily modified. Considering that Prost had been integrated the public buildings to the area, these features can be seen in a small part such as stadium, AKM, amphitheater (they are corresponding to $10 \%$ of the total built-up area).

Despite the removal a large percentage of the green spaces, the Gezi Park still presents an important achievement of the remnants of the legacy Prost. It was the first planned public park of the Republican Period of Turkey and is still being used as a public park.

In this study, digital tools have helped to understand qualitative and quantitative notions of Prost's legacy on the area. By the 3D modeling techniques and processing the data by ArcGIS, the visualization of the relationship between these notions and the topography and plan settlement has helped to investigate the fundamental principles of his planning decision as well as the change the history of Istanbul and understanding the Cultural Heritage. 


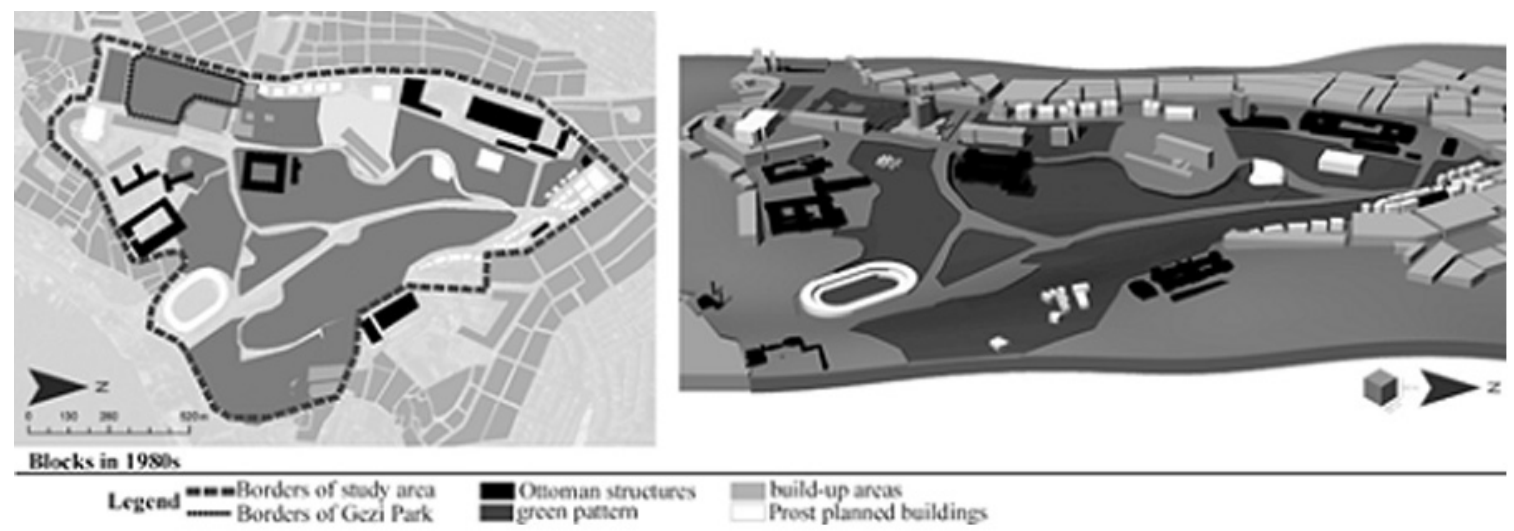

Figure 3. Blocks in 1980s; Basemap World Imagery and the information from 1:2000 Plan de Reference-1940 (Leveau,1960) and the information in aerial photos (IBB Map Collection) are spatialized by the author (Software: ArcGIS\& Rhinoceros)

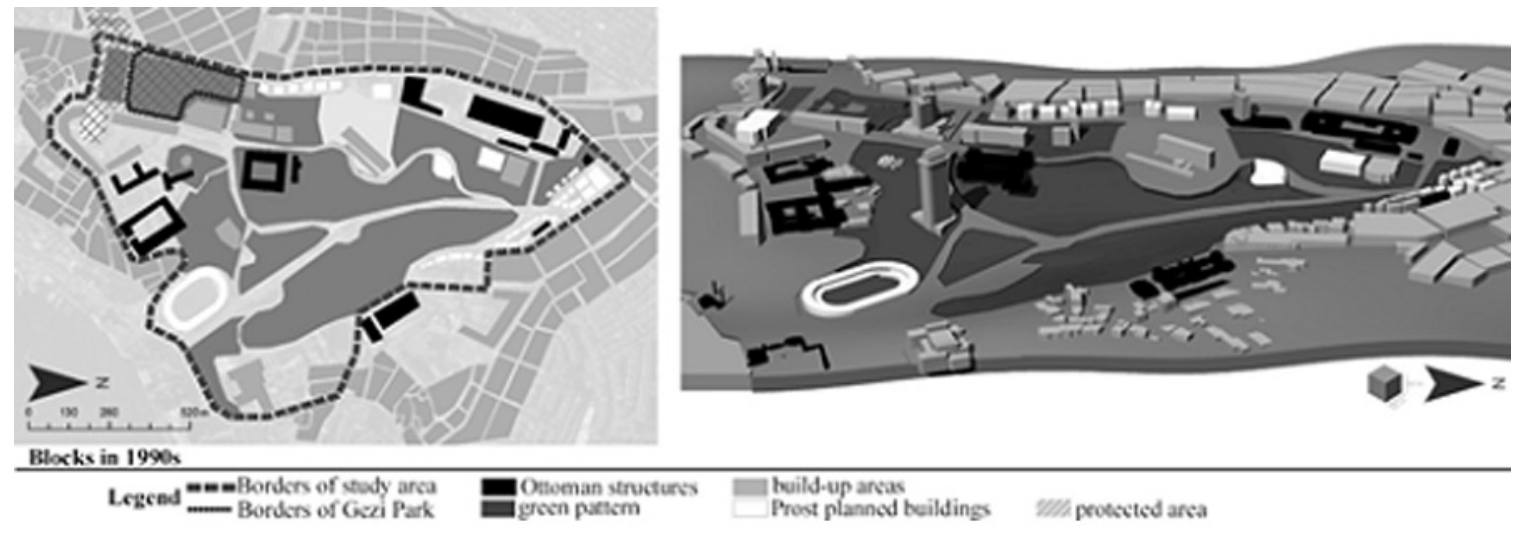

Figure 4. Blocks in 1990s; Basemap World Imagery and the information from 1:2000 Plan de Reference-1940 (Leveau,1960) and the information in aerial photos (IBB Map Collection) are spatialized by the author (Software: ArcGIS\&Rhinoceros)

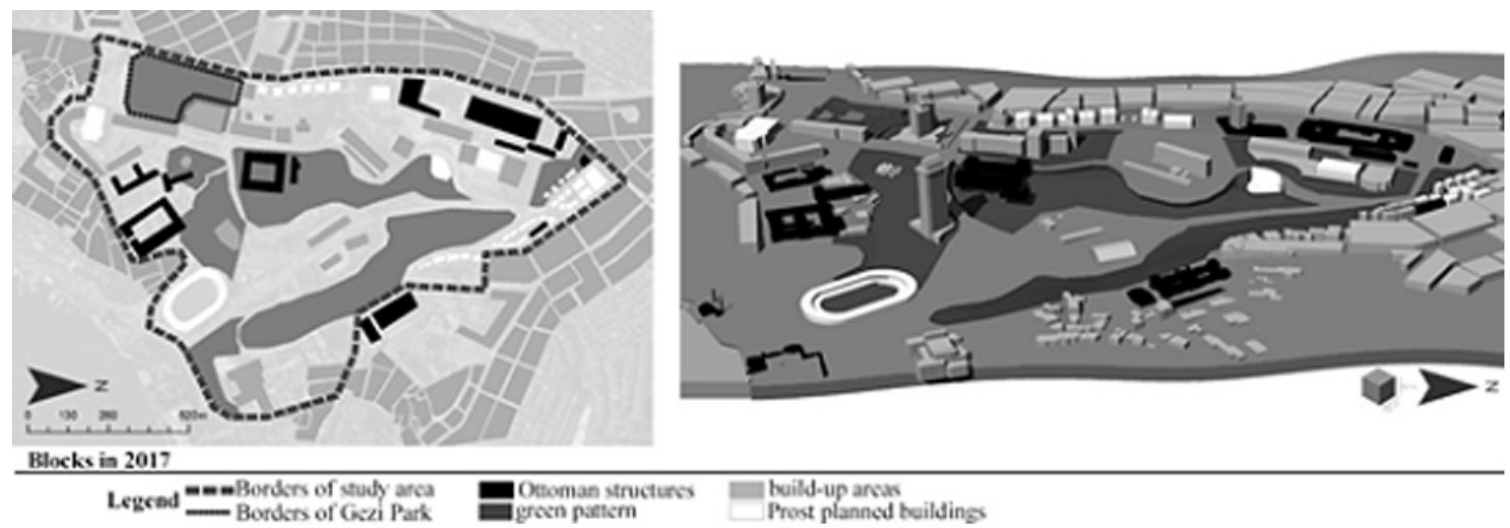

Figure 5. Blocks in 2017; Basemap World Imagery and the information from 1:2000 Plan de Reference-1940 (Leveau,1960) and the information in aerial photos (IBB Map Collection) are spatialized by the author (Software: ArcGIS\& Rhinoceros) 


\section{References}

Akpınar. İ. (2010) The Making of a Modern Pay-1 Taht in Istanbul: Menderes' Executions after Prost's Plan. From the Imperial Capital to the Republican Modern City: Henri Prost's Planning of Istanbul (1936-1951), İstanbul Research Institute.

Akpınar, İ. (2014) The rebuilding of İstanbul revisited: Foreign planners in the early Republican years.

New Perspectives on Turkey, 50, 59-92.

Bilsel, C. (2010) Espaces Libres: Parks, Promenades, Public Squares.... From the Imperial Capital to the Republican Modern City: Henri Prost's Planning of Istanbul (1936-1951), İstanbul Research Institute.

Bodenhamer, D. J., Corrigan, J., \& Harris, T. M. (2010). The spatial humanities: GIS and the future of humanities scholarship. Indiana University Press.

Bozdoğan, S. (2002) Modernism and nation building: Turkish architectural culture in the early republic. University of Washington Press.

Bozdoğan, S. \& Akcan. E (2013) Turkey: Modern Architectures in History. Reaktion Books,

Cohen, J . (2010) From Grand Landscapes To Metropolises: Henri Prost. From the Imperial Capital to the Republican Modern City: Henri Prost's Planning of Istanbul (1936-1951), İstanbul Research Institute.

Çelik, Z. (1993) The remaking of Istanbul: portrait of an Ottoman city in the nineteenth century. Univ of California Press

Çiftçi, A. (2004) '19.yüzyılda Osmanlı Devleti'nde askeri mimari ve İstanbul'da inşa edilen askeri yapılar' $\mathrm{PhD}$ thesis, YTÜ Fen Bilimleri Enstitüsü

Dinçer, İ., (2010) Türkiye'de 1980 Sonras1 Yapısal Dönüşümün Mekansal İzlerine Bir Örnek: Yenileme Alanları, Mimarlık

Enlil,Z. (2011) The neoliberal agenda and the changing urban form of Istanbul. International Planning Studies

Fonds HenriProst(2012)Expositions VirtuellesHenri Prost et le plan directur d'Istanbul IFA, Centre D'archives D'architecture Du XXe Siècle (archiwebture.citechaillot.fr/fonds/ FRAPN02_PROST/inventaire) accessed 14 June 2017.
Güzelleșen Istanbul (1943) XX.nci Y1l (haz. Abidin Daver-Safa Günay), Istanbul Municipality

Hautecoeur,L.(1960) Henri Prost A La Villa Medicis. L'Oeuvre de Henri Prost: architecture et urbanisme. Academie d'Architecture.

HarvardMapCollection(2009)Pland'Ensamble De La Villa De Constantinople (http://vc.lib. harvard.edu/vc/deliver/ maps/010779481) accessed 14 June 2017.

IBB Map Collection (2016) City Maps (https:// sehirharitasi.ibb.gov.tr/) accessed 14 June 2017.

Leveau,T.(1960) Istanbul. L'Oeuvre de Henri Prost: architecture et urbanisme. Academie d'Architecture.

Official Gazette Online Archive (2006) Legislation on 13.07.1984 (http://www. resmigazete.gov.tr/default.aspx\#) accessed 14 June 2017.

Prost,H. (1937) Istanbul'un Yeni Çehresi Nazım Planlar IIII. In: Özler,Ş. (ed.2007) Cumhuriyet dönemi İstanbul planlama raporlar1 1934-1995. UCTEA The Union of Chambers of Turkish Engineers and Architects, Istanbul Branch

Pinon, P. (2010) The Urbanism Of Henri Prost And Transformations Of Istanbul. From the Imperial Capital to the Republican Modern City: Henri Prost's Planning of Istanbul (1936-1951), İstanbul Research Institute.

Tamborrino,R. (2014) Digital Urban History. Telling the History of the City in the Age of the ICT Revolution. Roma: Croma

Tekeli, İ. (1996) 19. Yüzyılda İstanbul Metropol Alanının Dönüşümü. Modernleşme Sürecinde Osmanlı Kentleri, İstanbul: Türkiye Ekonomik ve Toplumsal Tarih Vakfi Yayını

UCTEA Istanbul Branch Online Archive (2014) Taksim Dayanışması Güncesi (http:// arsiv.mimarist.org/taksim-gezi-parkiguncesi.html) accessed 14 June 2017.

Warwick, C., Terras, M., \& Nyhan, J. (Eds.). (2012). Digital humanities in practice. Facet Publishing. 